\title{
Psychosemantic Content of the Concept of Sexuality in the Language Consciousness of Adults
}

\section{Психосемантичний зміст поняття сексуальності в мовній свідомості дорослих}

\begin{abstract}
Andrii Shevtsov
Dr. in Special Education Sciences,

Professor, Corresponding Member of the National Academy of

Educational Sciences of Ukraine
\end{abstract}

\author{
Андрій Шевцов \\ доктор педагогічних наук, \\ професор, \\ член-кореспондент Національної \\ академії педагогічних наук України
}
Viktoriia Hupalovska
Ph.D. in Psychology,
Associate Professor

E-mail: dr_shevtsov@ukr.net

https://orcid.org/0000-0002-7307-7768

ResearcherID: AAL-7418-2020

\section{Вікторія Гупаловська}

кандидат психологічних наук, доцент

$$
\begin{aligned}
& \text { E-mail: vktoriia.hupalovska@gmail.com } \\
& \text { https://orcid.org/0000-0002-5994-2102 } \\
& \text { ResearcherID: AAF-6070-2019 }
\end{aligned}
$$

National Pedagogical

M. Dragomanov University

$\triangle$ 9, Pyrogova Str., Kyiv,

Ukraine, 01601
Національний педагогічний університет ім. М.П. Драгоманова

$\triangle$ вул. Пирогова, 9, Київ, Україна, 01601

Original manuscript received June 17, 2019

Revised manuscript accepted March 10, 2020

\begin{abstract}
Introduction. The article presents the results of psycho-linguistic study of the representation in the linguistic consciousness, psychosemantic and psychological content of the relative neologism "sexuality" formed in the conditions of natural


transcultural semiosis. Herein the author's own definition of the phenomenon of sexuality was formulated.

The aim of the study is to research the semantic content of the concept of "sexuality", to analyze the existing definitions, to accentuate the concept of sexuality. On the basis of the results of psycho-linguistic and psychosemantic studies to formulate author's own definition.

Research Methods \& Techniques. The psycho-linguistic methods were used: (a) extended word association experiment; (b) modified semantic differential method; (c) modified incomplete sentence method.

Results. The extended word association experiment has shown that in the linguistic consciousness of the student's youth (20-22 years), in the understanding of sexuality, most often there exist semantic associates to "sexy" $(28,27 \%)$ calqued from the American English. In the associative field of persons the age of early adulthood, who have grown up in the conditions of natural linguistic semiosis, where there was no meaning of "sexy", other verbal reactions prevail, namely trust, openness, safety, reason, a man. The modified unfinished sentence method revealed that the psychosemantic understanding of sexuality in men and women has both common and distinct features.

Conclusions. The living word represents the cognitive-discursive activity of the individual and the society. Sexuality as a product of natural linguistic semiosis and as a psychological phenomenon is not reduced to sexual physicality. Being the part of a holistic self-concept and a meaningful identity, the concept of sexuality reaches the mental-spiritual level and is actively present in the linguistic consciousness of the adult. Therefore, sexuality functions on the physical, psycho-emotional and mental-spiritual levels and is considered in at least biological, psychological (psycholinguistic) and cultural aspects.

Key words: linguistic consciousness, associative fields, semantic space, associative experiment, psychosemantics of sexuality, sexuality.

\section{Вступ}

Сьогодні, в епоху глобалізації, сучасне людство живе в умовах віртуального стирання меж між державами завдяки можливостям сучасних систем комунікацій, в умовах взаємопроникнення культур, стирання меж між різними когнітивними системами світосприйняття, до транслінгвістичного поширення понять, запозичення термінів і значень. Деякі слова і поняття запозичуються разом із значеннями, деякі ж запозичення здатні трансформуватися, об’єднуватися 3 культуральним семантичним «грунтом», на який вони потрапили. Саме живе слово $є$ репрезентантом когнітивно- 
дискурсивної діяльності як індивіда, так і соціуму. Тому перед психолінгвістикою часто постає питання дослідження природного семіозису, визначення психосемантики, змісту понять на рівні суб'єктивної індивідуальної або ж суспільної мовної свідомості, які в подальшому формують світогляд та поведінку людей. Саме психолінгвістика володіє потужним науковим методичним інструментарієм, сукупністю методологічних підходів, моделей, методів, методик, які дають змогу отримати результати досліджень психологічного змісту (індивідуальних і групових) значень і систем значень. Адже завданням психології суб'єктивної семантики якраз і $€$ «дослідження та реконструкція (виявлення, опис і моделювання) не завжди зовні проявлених структур субъєктивного досвіду (систем значень і смислів), на основі якого будується образ світу людини (парадигмальна, частіше словесна, модель). У свою чергу, образ світу розглядається як складова свідомості» (Серкин, 2016).

В. Петренко у праці «Основы психосемантики» (Петренко, 2010), попри багато іншого, аналізує «культурологічну відносність» картини світу на основі особливостей синтаксичної структури мови у представників різних народів (наприклад, в індіанців племені навахо). Екстраполюючи цей підхід на людську індивідуальність, конструювання понять людиною лише засобами мови, можна стверджувати, що розуміння кожного поняття (наприклад, сексуальність чи сексуальне благополуччя) відображатиметься певним індивідуальним набором характеристик та суджень та впливатиме безпосередньо на життя та благополуччя людини. Причому цей процес має культурну забарвленість, те, якими словами послуговуються носії мови для позначення, опису сексуальності, властиве лише їхній культурі і буде відображатися у способі життя (сексуального в тому числі) носіїв цієї мови. Це надзвичайно важливий момент в історії поняття «сексуальність», адже походження слова, як і походження сексології як науки, американське. Відтак у контексті даного дослідження нам близьке розуміння мовної свідомості як репрезентанта не лише мовної діяльності, а й життєдіяльності, формування світоглядних понять в умовах природного семіозу. Російська етно-лінгвіст С.Є. Нікітіна (Никитина, 1993) та вітчизняний учений-мовознавець П.О. Селігей (2009) вказують на зумовленість мовної свідомості рисами 
особистості, такими як культурний статус, соціальна належність, стать, вік, світогляд, психологічний тип. Саме у такому контексті ми й розглядатимемо представленість досліджуваного поняття у мовній свідомості дорослих.

Інтерес до сексуальності людини та ii проявів завжди був досить високий. Незважаючи на значне розширення останнім часом теоретичних уявлень в даній сфері, не вщухають наукові дискусії стосовно визначення самого поняття сексуальності. Розуміння цього феномену пересічними людьми, носіями цієї ж сексуальності, також доволі суперечливе, наповнене «білими плямами» неусвідомленості, не розуміння самого себе та інших, багате низькопробними кліше, нічим не обгрунтованими установками, стереотипами, нав'язаними інтернет-порноресурсами. В результаті суспільна свідомість наповнена невизначеністю, суперечностями, а наукові кола контраверсійними дискусіями.

Небезпека такої невизначеності полягає у так званій «біхевіоральності» мови, пї близькості до поведінки. Адже багато що $з$ почутого або оформленого в думках за допомогою мови у формі суджень, поглядів «виливається» у поведінку. За твердженням Н.В. Романової, психологи-біхевіорісти Чарлз Осгуд, Джон Керолл та літературознавець, семіотик Томас Сібен, котрих вважають одними із засновників психолінгвістики, в якості вихідної схеми аналізу вважали формулу «стимул - асоціативний зв'язок - реакція». Стимул може мати різну форму: як вербальну (звук, склад, слово, словосполучення, речення, текст тощо), так і невербальну (музика, живопис, театр, кіно тощо) (Романова, 2012). А от реакцією може бути інше слово або ж поведінка людини. Таким чином, слово формує наш понятійний апарат, наші погляди, а відтак і поведінку. Мова також $є$ інструментом нейролінгвістичного програмування (мимовільного та довільного) (Ковалевська, 2001), тому семіотика поняття «сексуальність» може мати прямий стосунок до ціннісного наповнення та статево-поведінкового арсеналу сучасної молоді.

Отже, метою нашого дослідження $\epsilon$ вивчення психосемантичного наповнення поняття «сексуальність», аналіз наявних поглядів, увиразнення поняття сексуальності на основі результатів психолінгвістичного дослідження. 


\section{Методи та методики дослідження}

Для виконання поставлених завдань доцільно скористатися методом психосемантичного аналізу, методом семантичного диференціалу (Osgood, 1964), модифікованим методом незакінчених речень та асоціативним експериментом (Засєкіна \& Засєкін, 2008), який сьогодні називають «ефективним методом дослідження глибинних закономірностей у мереживі сенсорних кореляцій загальної архітектоніки людської свідомості» (Ковалевська, 2001: 249). Використовуватимемо продовжений асоціативний експеримент (Курганова, 2019).

\section{Результати та дискусії}

Психолінгвістичні дослідження тематики інтимних відносин стосувалися, зокрема, гендерних відмінностей. Наприклад, стосовно того, хто більше говорить - чоловіки чи жінки, і кого більше слухають (Кембріджський університет) (Curter \& Scott, 1990). 3 точки зору психолінгвістичного аналізу головні праці також присвячено відмінностям у мовній поведінці чоловіків і жінок, наприклад, стаття Deborah Cameron (Cameron, 2010) в журналі «Applied Linguistics». Ще одна авторка (Gawda, 2019) робить висновок, що відповідні лінгвістичні доказові дослідження гендерних відмінностей у мовній поведінці не пояснюються біологічними особливостями статей; а більш адекватно інтерпретуються із використанням соціокультурних підходів, яким надає перевагу більшість лінгвістичних дослідників.

У деяких працях, зокрема Сергія Воркачова (Воркачёв, 2007), Барбари Гавди (Gawda, 2019) з психолінгвістичної позиції аналізується концепт «любов». У монографії С. Воркачова (Воркачёв, 2007) узагальнюються лінгвістичні погляди на концепт як на ментальний утвір, забарвлений етнокультурною специфікою, що знаходить своє мовне вираження. На матеріалі російської мови досліджуються понятійна, метафорично-образна і значимісна складові семантики концепту «любов», його міждискурсна, вікова і гендерна варіативність та асоціативні властивості. «Сексуальність» же, не дивлячись на факт запозичення 3 американської 
англійської мови, поки що не стала предметом належної уваги психолінгвістичних студій.

Етимологічний словник украӥнської мови (Мельничук, 2006: 206) констатує, що термін «сексуальний» походить через середньоанглійське «sexe» і старофранцузьке «sexe» від латинського «sexus» («стать»), яке утворене від дієслова secare («різати», «відрізати») з первісним значенням «поділ», «відділення». Йдеться, імовірно, про поділ на статі. Однак, секс у розмовній мові означає також статеві зносини у людей та тварин. Отже, уже на пересічномовному рівні відбувається спрощення статевих проявів, зведення їх до одного виду статевої поведінки і статевості - статевого акту. Приблизно таке спрощення розуміння сексуальності знаходимо у більш ранніх дослідженнях і теоріях сексуальності, які можна назвати медико-біологічними та такими, що базуються на теорії психоаналізу, а відтак трактують сексуальність (1) як елементарний фізіологічний прояв, подібно до травлення чи дефекації, (2) як інстинкт, вроджений рефлекс на рівні організму, який діє за принципом елементарного парового котла, накопичуючи енергію та прагнучи розрядки (Кон, 2004).

Наприкінці 90-х років у пострадянському мовному просторі з’явилося слова «секс», «сексуальний», «сексуальність», усталилося розуміння останнього у значенні привабливості, атракції. Цей процес i його наслідки поки що не стали предметом наукових досліджень. Можна припустити 3 високою мірою імовірності, що походження такого розуміння на побутовому рівні англо-американо-мовне. Адже у психології відомий феномен впливу засобів масової інформації на масову свідомість, який у даному випадку реалізовувався голлівудським кінематографом шляхом трансляції 3 широкого екрану i «прививанням» українській та російській мові нового для пострадянського простору слова «сексуальний/сексуальна» (від англ. «sеху» - сексуально привабливий, привабливий/а).

Зважаючи на введене ще О.Ю. Артем'евою (Артемьева, 1999) розуміння сенсу як сліду діяльності i формування на основі цього психології суб'єктивної семантики, маємо підгрунтя для припущення, що вищеописані процеси матимуть своє відображення у мовній свідомості представників ранньої дорослості (20-40 років), а особливо - у наймолодших репрезентантів віку ранньої дорослосі (20-22 роки), чий період найбільшої пластичності психіки 
(дитинство) припало саме на час появи слів «секс» та «сексуальний» (у розумінні привабливий) у нашому мовному середовищі. Адже саме подібні процеси, як на то вказувала О. Артем'єва, є проявом функціонування та актуалізації слідів діяльності, які регулють структурну презентацію світу суб'єктом і впливають на всі форми його поведінки (Там само).

За допомогою продовженого асоціативного експерименту (extended word association test (EWAT)) (Курганова, 2019) серед 78 осіб раннього дорослого віку (20-22 роки) вдалося виявити, що ядерною зоною (частота 11,45\%) асоціативного поля слова «сексуальність» є краса (12), секс (12), периферію ядра з частотою 4,67-8,41\% утворюють привабливість (9), зовнішній вигляд (9), тіло (6), пристрасть (6), жінка (5). Перехідну зону асоціативного поля (частота 2,80-3,73\%) становлять грація (4), впевненість (4), ніжність (4), харизма (4), поведінка (4), бажання (4), відчуття (3), запах (3), романтика (3), стать (3), захоплення (3), стать (3), запах (3), відчуття (3), манери (3), пара (3) та інші (Табл. 1). Негативні конотації відсутні, нульових значень немає. Середня кількість реакцій на стимул в однієї людини - 3-5.

Таблиця 1. Семантичний простір поняття «сексуальність» у групі 20-22 роки

\begin{tabular}{|c|c|c|c|c|c|}
\hline \multicolumn{6}{|c|}{ Частка асоціацій від загальної кількості асоціацій (у \%) } \\
\hline По $\mathbf{1 1 , 4 5 \%}$ & По $\mathbf{8 , 4 1 \%}$ & $5-6 \%$ & По $\mathbf{3 , 7 3 \%}$ & По $2,80 \%$ & По $1,87 \%$ \\
\hline Kpaca & Привабливість & $\begin{array}{l}\text { Пристрасть } \\
(5,54 \%)\end{array}$ & Грація & Романтика & Близькість \\
\hline \multirow[t]{8}{*}{ секс } & $\begin{array}{l}\text { зовнішній } \\
\text { вигляд }\end{array}$ & Тіло $(5,54 \%)$ & впевненість & захоплення & самопрезентація \\
\hline & & $\begin{array}{l}\text { Жінка } \\
(4,67 \%)\end{array}$ & ніжність & стать & елегантність \\
\hline & & & харизма & запах & проявленість \\
\hline & & & поведінка & відчуття & $\begin{array}{l}\text { демонстративність, } \\
\text { сила }\end{array}$ \\
\hline & & & бажання & манери & жіночність \\
\hline & & & & пара & посмішка \\
\hline & & & & & голос \\
\hline & & & & & $\begin{array}{l}\text { червоний, губи, } \\
\text { дотик, фігура, } \\
\text { вигин }\end{array}$ \\
\hline
\end{tabular}


Як бачимо 3 асоціативного ряду, лише незначна частина слів-асоціатів (29,96\%) стосуються фізично-тілесного рівня (секс, тіло, жінка, губи, фігура), інша незначна частина - торкаються зовнішнього вигляду, поведінки і відчуттів. Більшість асоціацій стосуються психологічних якостей (наприклад, ніжність, демонстративність) та абстрактних понять і цінностей (краса, грація, харизма, шарм, аура тощо). Переважають парадигмальні та тематичні асоціати.

Словесно-смислові асоціати до американського «sеху» виявилися у студентів 20-22 років лексико-семантичним ядром поняття «сексуальність». Цей факт вказує на те, що лінгвістична наявність запозиченого слова тягне за собою і поширення його калькованого значення. А засоби масової інформації здатні глобалізувати цей процес. Покоління дітей, які народилися в 1998-2000 роках, в дошкільному і молодшому шкільному віці асимілювали хвилю поширення англомовного аналогу і це призвело до закріплення серед них значення «sexy» - красивий, привабливий.

Хоча найчастіше асоціації стосуються трактування сексуальності як привабливості (краса, привабливість, зовнішній вигляд - 28,27\%), набагато більша їх частина - 71,73\% стосуються меншою мірою емоцій (пристрасть, захоплення $8,34 \%$ ), а більшою - конкретних понять, певних властивостей людини (розкутість, впевненість, хитрість, доглянутість, приємність, ввічливість) та іï абстрактно-ціннісних (витонченість, інтимність) і абстрактно-духовних характеристик (легкість, ілюзія, шарм, аура, енергія, здоров'я).

Тому можна зробити висновок, що сексуальність, якщо i $\epsilon$ потребою сучасної молоді чи явищем, їй притаманним, то вона не може бути зведена до фізично-тілесного рівня, рівня зовнішньої привабливості. Сексуальність сучасної молодої людини психологізована, не мислима без душевно-емоційних потреб i менталізована - сягає ментально-духовного рівня.

Наступний етап продовженого асоціативного експерименту проходив у групі старших осіб (96 опитаних віком 25-48 років), i виявив відмінні від попередньої групи результати.

Асоціативне поле слова «сексуальність» виглядає наступним чином. «Сексуальність» - довіра (надійність, безпека, відкритість, відвертість) (5), близькість (зв'язок, поєднання, інтимність, 
контакт) (5), розум (інтелект, гумор) (5), енергія (4), чоловік, коханещь (4), врода (краса, привабливість) (4), тіло (3), гращія (гнучкість) (3), релакс (розслаблення, відпочинок) (3), свобода (вільність, розкутість) (3), червона помада (червоний) (3), грайливість (загадка, натяк) (3), подружжя (сім'я, пара) (3), обійми, поцілунки (3), впевненість (2), жінка (2), рух (2), кохання (2), ніжність (2), пристрасть (2), сексуальний потяг (2), витонченість (2), фігура (2), любов до себе, любов (2), радість, погляд, життя, жіночність, спокусливість, агресивність, флірт, догляд, легкість, парадокс, стегна жіночі, гострий язик, кучеряве волосся, наполегливість, витривалість, запах, бажання, море, білизна, ніч, постіль, панчохи, окуляри, здоров'я, закоханість, ейфорія, натхнення, секс, дорослість, губи, характер, досягнення мети, діловий костюм, стрункий, одяг, посмішка, чистота.

Як бачимо, переважають тематичні та парадигмальні асоціати, відсутні реакції з негативною конотацією. У старшій за віком групі семантичне забарвлення помітно відрізняється від студентів - наявний «зсув» асоціацій в бік внутрішніх потреб і характеристик та тематичних асоціатів. Усі асоціати нестереотипні: найпоширеніші довіра, близькість, розум - 3 низькою частотністю (0,045). Центр семантичного поля не сформований - відсутні реакції з частотою більше $10 \%$, усі асоціати знаходяться в зоні ближньої периферії (найвища частота - 4,5\%). Це свідчить про семантичну неоднорідність, не сформованість поняття у даної групи осіб. Менше асоціацій, пов'язаних із зовнішніми ефектами та виглядом, які відповідають значенню американського «sеху», що більше притаманно студентам - поколінню, яке виросло у нашому мовному просторі, в якому таке значення слова «сексуальність» уже 3'явилося. Таким чином, ЗМІ та інші явища масової культури таки здатні непомітно формувати поняття і залишати цей слід в думках цілих поколінь.

Порівняно зі студентами, у групі, старшій за віком, привабливість і тілесні ознаки знаходяться далеко не на перших позиціях. Найважливішими для більшості $є$ довіра, надійність, близькість, безпека, контакт.

Цікавим є той факт, що у не студентів - більш дорослих осіб, імовірно, уже 3 досвідом стосунків, в асоціаціях проглядається різноманітність і характер сексуальної поведінки, певний 
сексуальний сценарій. Наприклад, в однієї особи (чоловік, 32 роки) сексуальність асоціюється 3 танцем, парою, гострим язиком, стегнами жінки, кучерявим волоссям, в іншої людини - 3 чоловіком, тілом, розумом, характером, діловим костюмом, досягненням мети, стрункістю. У третьої особи - 3 інтелектом, натхненням, грацією, гнучкістю, витонченістю, ейфорією. Можна сказати, що сексуально привабливою для першого чоловіка буде жінка 3 довгим кучерявим волоссям і стрункими стегнами, яка танцює й, імовірно, якщо він потрапить в таку ситуацію, чи споглядатиме іiі, то актуалізуватиметься сексуальна потреба. У випадку другої особи ми бачимо образ сексуально привабливого для неї чоловіка. У третьої особи сексуальна потреба $є$ витончено емоційно-ментальною, i це або ï особисті характеристики, або ж властивості потенційно сексуально привабливого партнера.

Для більш глибокого виявлення семантичного наповнення поняття сексуальності ми використали також метод семантичного диференціалу. В якості полярних характеристик було підібрано низку якостей, які опитувані співвідносили 3 поняттям «сексуальність» $\mathrm{i}$ могли оцінити за шкалою від 0 до 5. Полярні характеристики були обрані нами не випадково - це властивості сексуальних сценаріїв, узагальненими нами за характеристиками, представленими у доробку низки авторів (Sakaluk et al., 2014; Snell et al., 2001; Suvivuo, Tossavainen \& Kontula 2010; Тёмкина, 2008).

Найбільш вираженими характеристиками поняття сексуальність в розумінні молоді $є$ : у дівчат - сексуальність «романтична», «€ набуттям досвіду», «€ самореалізацією», грайлива, «є обміном», «є товаром», «потребує певних умов» (Рис. 1).

У молодих чоловіків актуальними $є$ інші характеристики сексуальності: найвищий показник - сексуальність «потребує умов», далі подібно до дівчат «є набуттям досвіду», «є самореалізацією», потім - сексуальність «романтична», «є товаром», «€ обміном», «раціонально не контрольована». Отже, як бачимо, хлопці підходять більш раціонально до сексуальності, не дивлячись на те, що охарактеризували сексуальність як раціонально не контрольовану, вона «потребує умов». Дівчата ж мають більше романтичних очікувань.

Молоді жінки найменш притаманними сексуальності вважають іiі репродуктивність та подібність до батьків, найменше 
вважають іï сферою, яка дає свободу. Серед молодих чоловіків найменш притаманними сексуальності характеристиками були: «така, як у батьків», «дружня», «закохана», «дає свободу». Отже, молодь відчуває обмеження, пов'язані з сексуальністю, не відчуває можливості бути вільними у цій сфері, не хоче бути подібною до батьків.

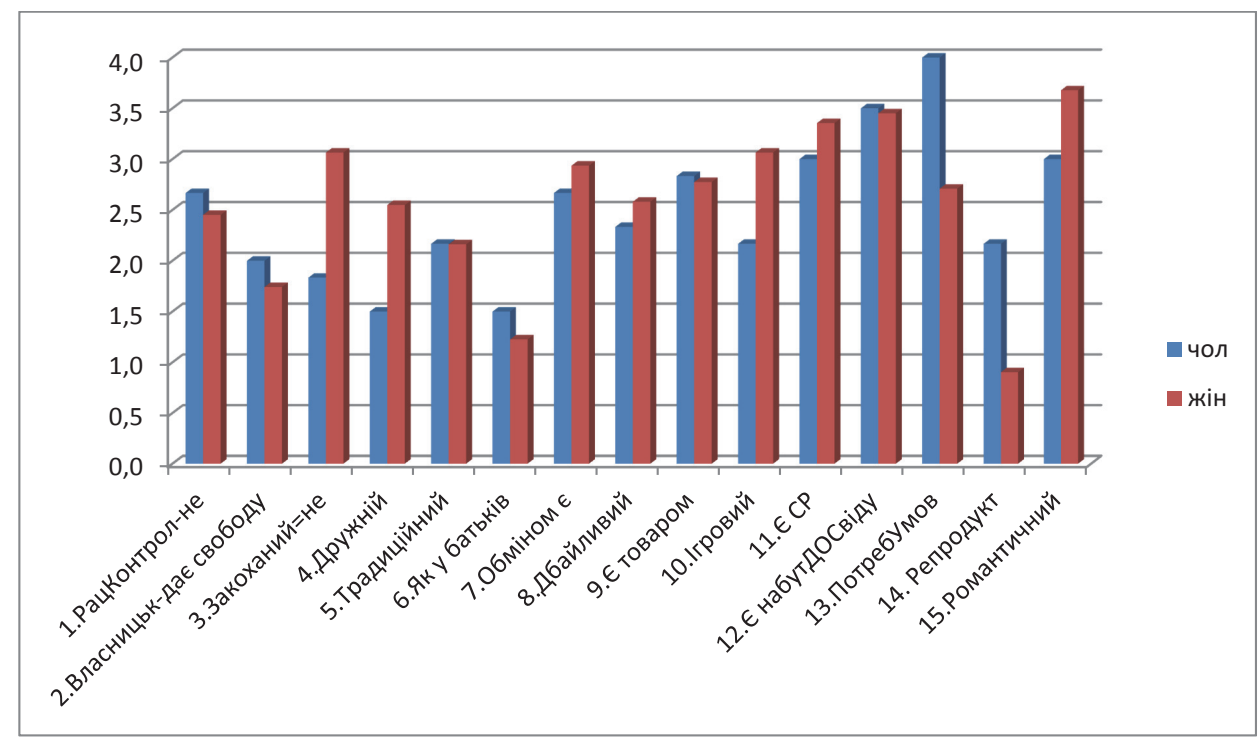

Рис. 1. Середні значення семантичного диференціалу стосовно поняття «сексуальність» у групах молодих чоловіків та жінок

Характер даних (наявність нормального розподілу) дав змогу нам статистично опрацювати результати - застосувати параметричний Т-критерій Стьюдента для порівняння середніх показників семантичними характеристиками поняття «сексуальність» між чоловіками та жінками. Було виявлено, що існують статистично значущі відмінності за характеристиками: «закоханий», «грайливий» (вищі значення у дівчат (при $\mathrm{p} \leq 0,01-0,05)$ ), «потребує умов», «репродуктивний» (вищі у хлопців (при $\mathrm{p} \leq 0,01)$ ).

Аналогічно за Т-критерієм Стьюдента ми здійснили порівняння середніх показників характеристик, виявлених методом семантичного диференціалу, поняття «секс» між чоловіками та жінками (Рис. 2). 


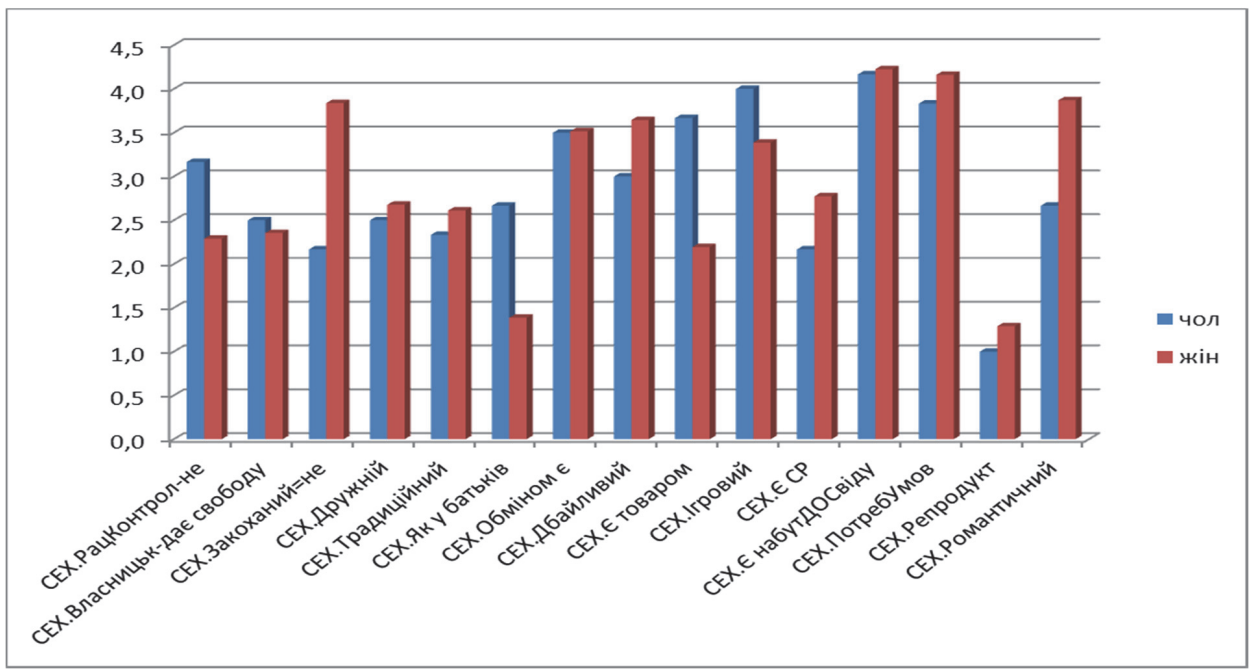

Рис. 2. Середні значення семантичного диференціалу стосовно поняття «секс» у групах молодих чоловіків та жінок

Статистично значущими виявилися відмінності: «раціонально не контрольований», і «як у батьків» (вищі значення у хлопців (при $\mathrm{p}=0,006))$ i «закоханий» (вище значення у дівчат (при $\mathrm{p}=0,0001)$ ). Якщо порівняти характеристики понять «сексуальність» і «секс» у хлопців (див. рис. 3), то видно, що секс хлопці переважно наділяють вищими балами. У «сексуальності» вищі оцінки лише за потребою умов, романтичністю, «є самореалізацією» і за репродуктивністю. Найвищі бали у хлопців секс набирає за характеристиками (в порядку спадання): є набуттям досвіду, ігровий, потребує умов, $\epsilon$ товаром, $є$ обміном, раціонально не контрольований, дбайливий. Як видно 3 рис. 3, у молодих чоловіків секс набагато більше, ніж сексуальність, є набуттям досвіду, грайливим (ігровий підхід, розважальний сценарій), є товаром і підлягає обміну, є більш дбайливим, дружнім і як у батьків. Це вказує на те, що секс справді асоціюється зі статевим актом і носить у хлопців більш розважально-обмінний характер.

Для порівняння - у розумінні дівчат сексуальність більше $є$ самореалізацією і товаром і більш раціонально неконтрольована, ніж секс (Рис. 4). За усіма іншими характеристиками, як і в хлопців, секс отримує сміливіші, вищі оцінки. 
Психосемантичний зміст поняття сексуальності в мовній...

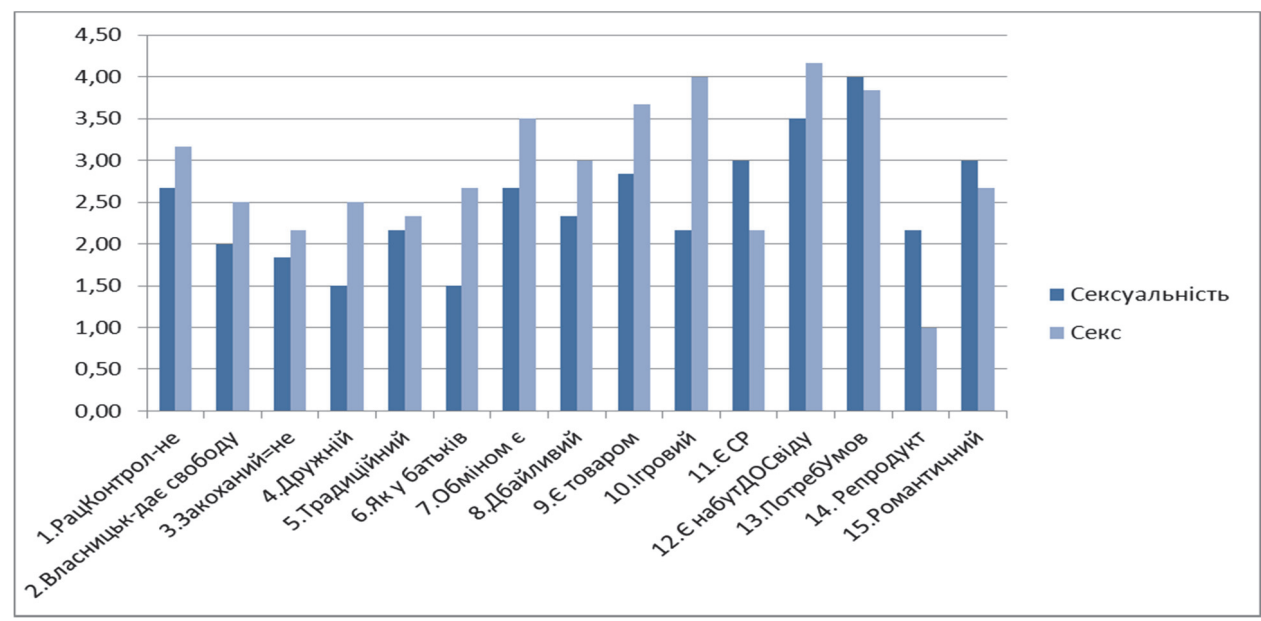

Рис. 3. Середні значення семантичного диференціалу стосовно понять «сексуальність» $i$ «секс» у групі молодих чоловіків

Підсумування результатів асоціативного експерименту та модифікованого методу семантичного диференціалу дало нам змогу виявити психолінгвістичні та психосемантичні особливості поняття «сексуальність» у мові та масовій свідомості. Тепер можемо їх порівняти із визначеннями сексуальності, що їх давали і дають науковці.

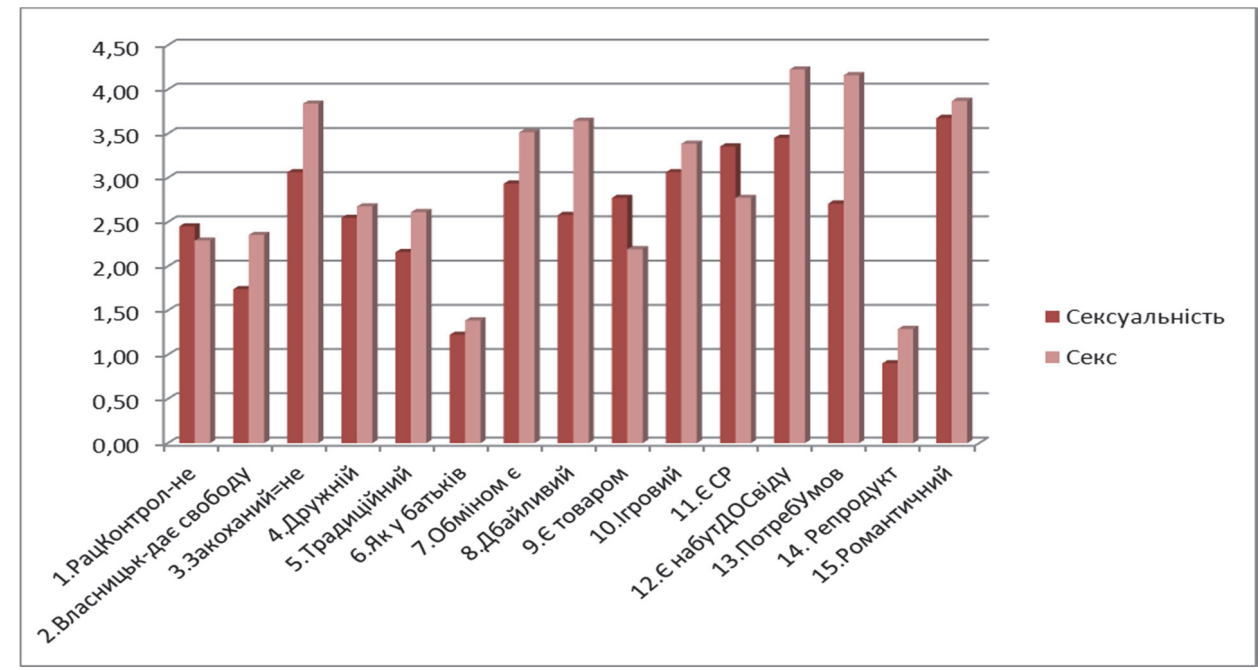

Рис. 4. Середні значення семантичного диференціалу стосовно понять «сексуальність» $i$ «секс» у групі молодих жінок 
Згідно 3 визначенням ВО3 (Стандарты сексуального образования в Европе, 2010: 19), у широкому розумінні «сексуальність людини $є$ природною частиною розвитку людини на кожному етапі життевого циклу і містить в собі фізичні, психологічні і соціальні складові»

У 2006 році комісія ВОЗ уточнила, що входить до цього поняття: «Сексуальність є центральним аспектом буття людини протягом усього піi життя і включає в себе стать, гендерні ідентичності та ролі, сексуальну орієнтацію, статевий інстинкт, задоволення, близькість і репродукцію. Сексуальність проявляється i виражається в думках, фантазіях, бажаннях, переконаннях, установках, цінностях, вчинках, поведінці, статевих ролях i стосунках. Не дивлячись на те, що сексуальність може містити в собі усі ці аспекти, не всі вони одночасно відчуваються і проявляються. На сексуальність впливає сукупність біологічних, психологічних, соціальних, економічних, політичних, етичних, правових, історичних, релігійних та духовних чинників» (Стандарты сексуального образования в Европе, 2010: 19).

У психологічному науковому розгляді термін «сексуальність» пройшов свою довгу історію від психоаналізу i до сучасних гуманістично-постмодерністських понять, змінюючись та еволюціонуючи. В психоаналізі сексуальність - це термін, який використовується для позначення задоволення, отриманого від будь-якої ділянки тіла чи органа, не тільки від геніталій (Агарков \& Кащенко, 2011). Психоаналітики слідом за 3. Фрейдом (Фрейд, 1998), який говорив про психосексуальний розвиток дитини, вважають це задоволення еротичним, сексуальним, хоча, на нашу думку, воно є радше лібідозним, відповідає принципові задоволення в широкому розумінні.

Багатоаспектність визначень спостерігаємо у наступних твердженнях, в яких прослідковується зсув акцентів від біологічних до психологічних та духовно-ментальних компонентів сексуальності:

- Сексуальність (за А. Лоуеном) - біологічний процес, який залежить від наявності надлишкової енергії, яка необхідна для його здійснення (цит. за: Кон, 2004).

- Сексуальність (за Ю.П. Зінченком) - «психологічне утворення, яке володіє ознаками вищої психічної функції, характеризується ієрархічною будовою, прижиттєвим, 
соціальним характером формування, знако-символічною опосередкованістю і довільністю» (цит. за: Айзман, 2012)

Погляди відомого дослідника сексуальності людини І.С. Кона (2004) з часом еволюціонували. Якщо у перших своїх працях він визначає сексуальність як характеристику сексуального потягу, сексуальних реакцій, сексуальної активності і т. ін. То пізніше зазначає, що сексуальність - стрижневий аспект буття людини протягом усього життя, включаючи стать, гендерні ідентичності i ролі, сексуальну орієнтацію, еротизм, задоволення, інтимність і репродукцію (Там само).

В українській мові існує слово «стать» і в рамках сексології, в рамках медико-біологічного підходу, коли йдеться про сексуальність як збудливість та здатність до сексуальної реакції, адекватно було б говорити про «статевість» українською. Ймовірно, причиною такого «зміщення» значення терміну «сексуальність» в бік медикобіологічного підходу є витоки сексологічних знань.

Класики світової сексології наполягали, що сексуальність людини виходить далеко за межі фізіологічної реактивності (Келли, 2000). Вони виокремлюють також 5 аспектів сексуальності, із яких лише 2 медико-біологічні: анатомо-біологічний аспект як основа виникнення сексуальності і клінічний аспект, який вивчає можливості лікування. Інші ж аспекти - психологічний, поведінковий, культурний, дослідники додають ще морально-етичний, соціальний, правовий - ставлять зовсім інші акценти у науці.

Таким чином, потреба у вивченні «психосексуальної активності людини» (термін Е.Кащенка) виходить за рамки сексології i добре вписується у контекст психології сексуальності (Агарков \& Кащенко, 2011). Але чи можна, чи варто ототожнювати статевість (статеву тілесність) і сексуальність?

Щоб дати відповідь на це питання проаналізуємо дані проведених нами опитувань за модифікованим методом незакінчених речень (Карелин, 2007). 3 метою з'ясування, що для опитуваних $\epsilon$ сексуальність, ми запропонували їм продовжити сформовані нами речення:

(1) Ваше сексуальне життя і Ваша сексуальність для Вас - це...

(2) Коли Ви думаєте про сексуальність, бачите, спілкуєтесь із привабливою сексуально людиною, то відчуваєте....

(3) Ваша сексуальність у Вас: 
А) викликає тілесні відчуття і переживання.

АА) викликає лише тілесні відчуття і переживання.

Б) стосується душевних переживань, активно задіює їх.

В) викликає трансцендентні переживання, сягає духовного рівня.

Ваш варіант

В опитуванні взяли участь 142 жінки і 135 чоловіків віком від 21 до 52 років. Результати порівняння середніх арифметичних між групами чоловіків та жінок представлені на рис. 5 та 6. Відповіді вдалося згрупувати у наступні пункти, які ми розмістили відповідно до ієрархії потреб у піраміді А. Маслоу (2004) (знизу, від базових фізіологічних, у даному випадку інстинктивних потреб, у висхідному напрямку до сексуальності як самореалізації):

Bac - це:

(1) Ваше сексуальне життя i Ваша сексуальність для

А) реалізація інстинкту продовження роду

Б) реалізація статевого потягу

В) прагнення задоволення

Г) бажання спілкування

Д) бажання відчути прийняття, прихильність, любов

Е) потреба близькості, інтимності

€) потреба бути потрібним/ою, оціненим/ою позитивно

Ж) моя самореалізація

Запитання 2 більше стосувалось відчуттів, емоцій, почуттів, які однак, $є$ тісно пов'язаними з потребами.

(2) Коли Ви думаєте про сексуальність, бачите, спілкуєтесь із привабливою сексуально людиною, то відчувасте:

А) активізацію, пожвавлення

Б) потребу в задоволенні

В) хочете поділитись своїми емоціями і щоб хтось виявив до Вас свою симпатію

Г) відчуваєте бажання зблизитись зі спорідненою душею

Д) потребу в коханні

Е) відчуваю любов до всього живого свою єдність зі світом, космосом.

Результати групування найпоширеніших відповідей ми розмістили в порядку від простіших і короткотривалих емоцій (пожвавлення, задоволення) до більш складних і стійких (кохання, любов). Результати були внесені у статистичну таблицю за допомогою 
присвоєння кожній відповіді 1 бала, якщо варіант відповіді збігається 3 виокремленим нами і 0 балів, якщо такої відповіді немає. Така система представлення результатів дала змогу здійснити статистичне опрацювання, виявити найпоширеніші відповіді у чоловіків та жінок і порівняти їх. В одній із груп опитаних (68 осіб), де чоловіки виявилися трохи релігійнішими, ніж жінки, статистично значущою є лише одна відмінність за бажанням відчути прийняття, прихильність, любов (при р=0,019) - вищі значення у жінок. Цікаво, що у цій групі, яка була зібрана нами з поодиноких опитувань методом «снігової кулі» (знайомі пропонують опитування своїм знайомим) у 2018 році, жінки виявилися більш гедоністично налаштовані (див. позначення на рис. 5 - 12.В) і тілесно-орієнтовані у розумінні сексуальності (14.А). Зазначимо, що частина опитаних здобувачки другої вищої освіти, а відтак жінки активні, пізнавально орієнтовані. Це узгоджується 3 даними Фрідріха і Штарке (Кон, 2004), професійно активні та самореалізовані жінки, чия діяльність пов'язана 3 когнітивною активністю, отримують більше задоволення від сексуального життя, ніж домогосподарки.

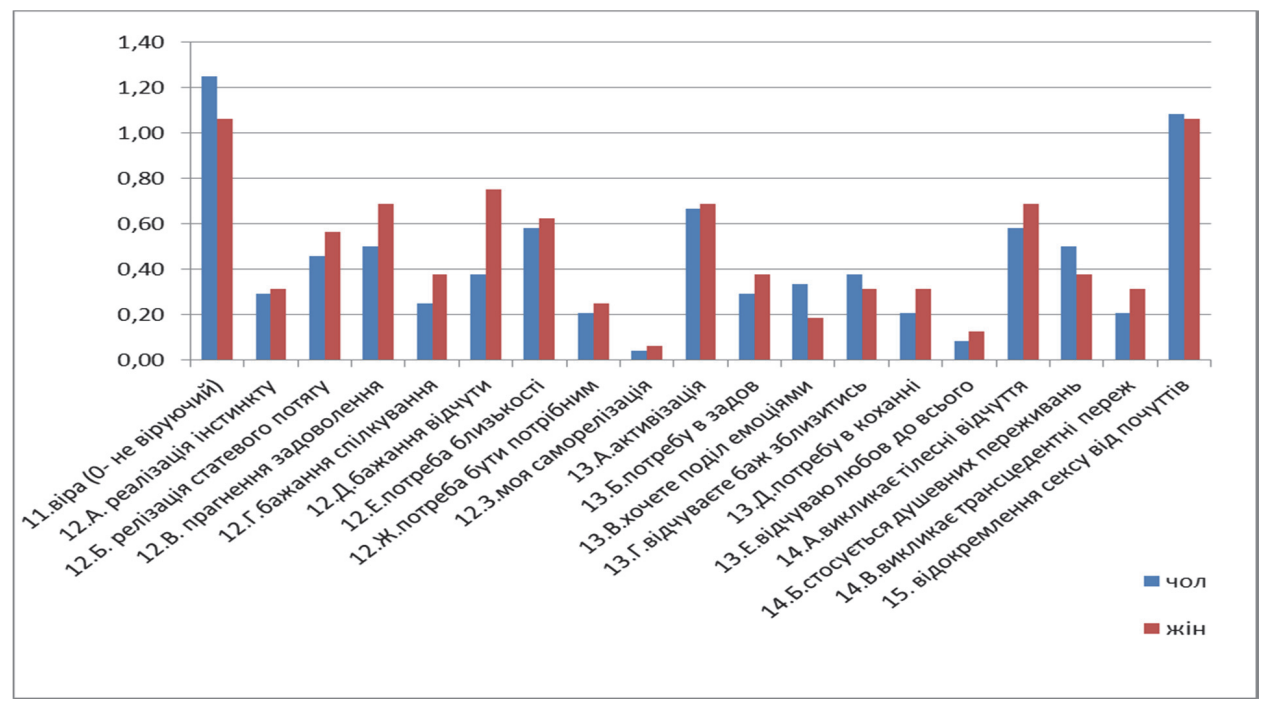

Рис. 5. Порівняння середніх арифметичних показників розуміння сексуальності чоловіками та жінками (метод незакінчених речень) (n=68)

В решти опитуваних (209 осіб) (Рис. 6) дані відмінні від вище приведених (Рис. 5), більш «традиційні». У чоловіків сексуальність 
викликає не виключно тілесні, але переважно тілесні відчуття (див. позначення на рис. 6 - 14.А - статистично значуща відмінність при $\mathrm{p}=0,0000)$, вони відчувають більшу активізацію у відповідь на думки чи сексуальні стимули (13.А), відчутно вищі показники розуміння сексуальності як прагнення задоволення (12.B, 13.Б), реалізації інстинкту продовження роду (12.А), статевого потягу (12.Б). Однак, у чоловіків, як і в жінок, великою мірою сексуальність є бажанням відчути прихильність, любов (12.Д) i душевну близькість, інтимність (12.Е).

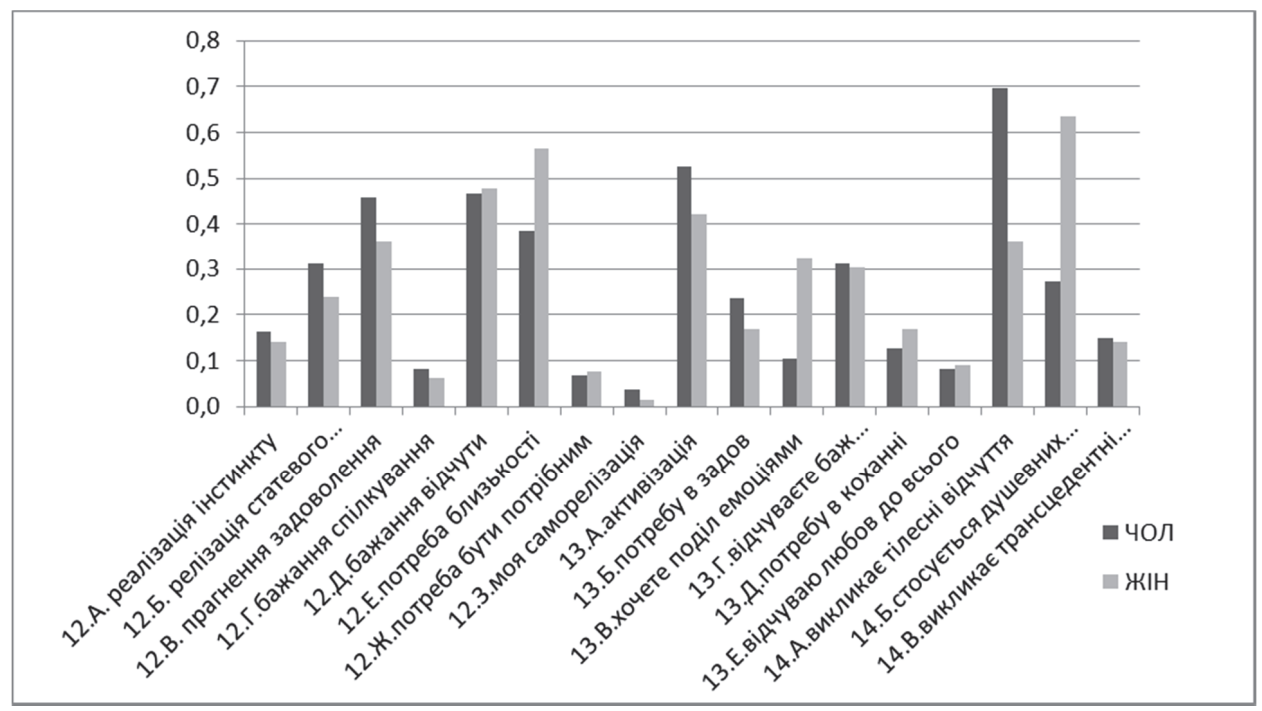

Рис. 6. Порівняння середніх арифметичних показників розуміння сексуальності чоловіками та жінками (метод незакінчених речень) (n=209)

У жінок сексуальність найвиразніше стосується душевних (емоційних) переживань (14.Б - статистично значуща відмінність при $\mathrm{p}=0,0000)$, сексуальність $є$ проявом потреби у близькості (12.Е - статистично значуща відмінність при $p=0,0029)$, є бажанням відчути прихильність, любов. Як бачимо, не у словесному, а більш психологічному у розумінні власної сексуальності у чоловіків переважає задоволення i прихильність, любов, а для жінок сексуальність - це близькість, любов, лише тоді задоволення.

Як бачимо, компонент емоційності, міжособистісний контекст важливий для обох статей i розуміння феномену сексуальності 
виходить за межі тілесності. Зазначимо також, що стабільно близько 14,81\% опитуваних і чоловіків, i жінок зазначають, що сексуальність викликає трансцендентні почуття (14.В), тобто відповідають духовному рівневі.

Прихильник концепції динамічної психіатрії Г. Аммон дає «зріле» визначення сексуальності. На його думку «конструктивна сексуальність, інтегрована в цілісну психічну активність індивіда, це здатність до встановлення зрілого партнерського симбіозу, як взаємно збагачуючого єднання самодостатніх особистостей, спрямованого на «відкриття» партнера, відчування його унікальності, а також безумовне тілесне, душевне і духовне злиття. Таке єднання не обумовлене виключно біологічними потребами, вільне від рольових фіксацій і страхів, що допускає можливість виходу 3 нього без руйнівного почуття провини і переживання втрати» (Аммон, 1996; Шаповалова, н.д.).

\section{Висновки}

Завдяки продовженому асоціативному експерименту вперше встановлено, що в мовній свідомості студентської молоді (2022 роки) віку ранньої дорослості найчастіше зустрічається кальковане 3 американської розуміння сексуальності - «меху» (сексуально привабливий). Однак, таке значення складає не більше $1 / 3$ усіх асоціацій.

У мовній свідомості респондентів представлені також особистісно-психологічні характеристики й абстрактні поняття. В осіб, які виросли в мовному просторі, в якому значення «sеху» ще не було вживаним у ЗМІ і не використовувалося їхніми батьками, переважають інші асоціати - довіра, відкритість, безпека, розум, чоловік.

За допомогою модифікованого методу незакінчених речень виявлено, що психосемантично розуміння сексуальності у чоловіків та жінок має як спільні (прагнення відчути прихильність, любов), так і відмінні риси (у чоловіків - прагнення задоволення, тілесні відчуття, у жінок - стосується душевних переживань, потреба близькості). Розуміння феномену сексуальності виходить за межі тілесності, як в психолінгвістичному, так і в психосемантичному ракурсі. 
Таким чином, завдяки психолінгвістичному та психологічному аналізу представленості поняття сексуальності у мовній свідомості можемо висловити більш цілісне, холістичне розуміння цього феномену. Сексуальність - багатоаспектне явище, біопсихосоціальний феномен, який формується на основі статевості, переживається людиною на інтрапсихічному рівні як комплекс анатомо-фізіологічних i психологічних характеристик та самоідентифікація і проявляється на поведінковому рівні (транслюється назовні) у вигляді статевої самопрезентації індивіда та прагнення до побудови міжособистісних (парних) стосунків. Будучи частиною цілісної Я-концепції та осмисленої ідентичності особистості, сягає ментально-духовного рівня. Сексуальність функціонуе на тілесно-фізичному, душевно-емоційному та ментально-духовному рівні i розглядається щонайменше в біологічному, психологічному та культуральному аспектах. Сексуальність можна вважати переживанням людиною своєї належності до статі (статевості) та способом прояву цієї належності.

\section{Література}

Агарков, С.Т., \& Кащенко, Е.А. (2011). Сексуальность от зачатия до смерти: онтогенез сексуальности. Воронеж: ИПЦ «Научная книга».

Айзман, Н.И. (2012). Особенности становления сексуальности у студенток вуза и ее гармонизация в условиях психологического воздействия. Автореф. дисс. канд. психол. наук. Томск.

Аммон, Г. (1996). Динамическая психиатрия. Санкт-Петербург: Изд-во НИПНИ им. В.М. Бехтерева.

Артемьева, Е.Ю. (1999). Основь психологии субъективной семантики. И.Б. Ханина (Ред.). Москва: Наука; Смысл.

Воркачев, С.Г. (2007). Любовь как лингвокультурный кониепт. Москва: Гнозис.

Маслоу, А. (2004). Мотиваџия и личность. Киев: PSYLIB.

Мельничук, О.С. (Ред.). (2006). Етимологічний словник украӥнської мови. (Т. 1-7). (Т. 5, с. 206). Київ: Наукова думка.

Засєкіна, Л.В., \& Засєкін, С.В. (2008). Психолінгвістична діагностика. Луцьк: РВВ Вежа.

Карелин, А. (2007). Большая эничиклопедия психологических тестов. Москва: Эксмо.

Ковалевська, Т.Ю. (2001). Комунікативні аспекти нейролінгвістичного програмування. Одеса: Астропринт.

Келли, Г. (2000). Основы современной сексологии. Санкт-Петербург: Питер.

Кон, И.С. (2004). Сексология. Москва: Академия.

Курганова, Н.И. (2019). Ассоциативный эксперимент как метод исследования значения живого слова. Вопросы психолингвистики, 3 (41), 24-37. https://doi. org/10.30982/2077-5911-2019-41-3-24-37 
Психосемантичний зміст поняття сексуальності в мовній...

Никитина, С.Е. (1993). Устная народная культура и языковое сознание. Москва: Наука.

Петренко, В.Ф. (2010). Основы психосемантики. Москва.

Романова, Н.В. (2012). Психолінгвістичні методи дослідження емотивної лексики. Режим доступу: https://naub.oa.edu.ua/2012/psyholinhvistychni-metodydoslidzhennya-emotyvnoji-leksyky/

Селігей, П.О. (2009). Структура й типологія мовної свідомості. Мовознавство, 5, $12-29$.

Серкин, В.П. (2016). Психосемантика. Режим доступу: https://stud.com.ua/43561/ psihologiya/psihosemantika

Тёмкина, А. (2008). Сексуальная жизнь женщины: между подчинением и свободой. Санкт-Петербург: Издательство Европейского университета в Санкт-Петербурге.

Фрейд, 3. (1998). Основные принщииы психоанализа. Москва: Рефл-бук.

Шаповалова, В.А. (Ред.). (н.д.). Терминологический глоссарий основных терминов динамической психиатрии. Режим доступа: http:/vocabulary.ru/slovari/ terminologicheskii-glossarii-osnovnyh-terminov-dinamicheskoi-psihiatrii.html

Стандарты сексуального образования в Европе. (2010). Режим доступа: http:// srhhivlinkages.org/wp/wpcontent/uploads/2013/04/who_bzga_standards_ru.pdf

Cameron, D. (2010). Sex/Gender, Language and the $\overline{N e w}^{-}$Biologism. Applied Linguistics, 31 (2), 173-192. https://doi.org/10.1093/applin/amp022

Cutler, A., \& Scott, D.R. (1990). Speaker sex and perceived apportionment of talk. Applied Psycholinguistics, 11 (3), 253-272. https://doi.org/10.1017/S0142716400008882

Gawda, B. (2019). The Structure of the Concepts Related to Love Spectrum: Emotional Verbal Fluency Technique Application, Initial Psychometrics, and Its Validation. Journal of Psycholinguistic Research, 48, 1339-1361. https://doi.org/10.1007/ s10936-019-09661-y

Osgood, Ch.E. (1964). Semantic differential technique in the Comparative Study of Cultures. American Anthropologist, 66 (3), 171-200. https://doi.org/10.1525/ aa.1964.66.3.02a00880

Sakaluk, J.K., Todd, L.M., Milhausen, R., Lachowsky, N.J., \& Undergraduate Research Group in Sexuality (URGiS). (2014). Dominant heterosexual sexual scripts in emerging adulthood: Conceptualization and measurement. Journal of Sex Research, 51 (5), 516-531. https://doi.org/10.1080/00224499.2012.745473

Snell, W.E.Jr., \& Rigdon, K.L. (2001). The Multidimensional Sexual Perfectionism Questionnaire: Preliminary evidence for reliability and validity. In W.E. Snell Jr. (Ed.), New Directions in the Psychology of Human Sexuality: Research and Theory (Chapter 15). Cape Girardeau, MO: Snell Publications.

Suvivuo, P., Tossavainen, K., \& Kontula, O. (2010). «Can There Be Such a Delightful Feeling as This?» Variations of Sexual Scripts in Finnish Girls' Narratives. Journal of Adolescent Research, 25 (5), 669-676. https://doi. org/10.1177/0743558410366597

\section{References}

Agarkov, S.T., \& Kashchenko, E.A. (2011). Seksualnost ot zachatiya do smerti: ontogenez seksualnosti [Sexuality from Conception to Death: The Genesis of Sexuality]. Voronezh: IPTS «Nauchnaya kniga» [in Russian]. 
Ayzman, N.I. (2012) Osobennosti stanovleniya seksualnosti u studentok vuza i yeye garmonizatsiya $\mathrm{v}$ usloviyakh psikhologicheskogo vozdeystviya [Features of the Formation of Sexuality Among University Students and its Harmonization in Terms of Psychological Impact]. Extended abstract of Candidate's thesis. Tomsk [in Russian].

Ammon, G. (1996). Dinamicheskaya psikhiatriya [Dynamic Psychiatry]. St. Petersburg: Izd-vo NIPNI im. V.M. Bekhtereva [in Russian].

Artemyeva, E.Y. (1999). Osnovy psikhologii subyektivnoy semantiki [Fundamentals of the Psychology of Subjective Semantics]. In I.B. Khanina (Ed.). Moscow: Nauka; Smysl [in Russian].

Vorkachev, S.G. (2007). Lyubov kak lingvokulturnyy kontsept [Love as a Linguistic and Cultural Concept]. Moscow: Gnozis [in Russian].

Melnychuk, O.S. (Ed.). (2006). Etymolohichnyy slovnyk ukrayinskoyi movy Etymological Dictionary of the Ukrainian Language. (Vols. 1-7). (Vol. 5, p. 206). Kyiv: Naukova dumka [in Ukrainian].

Zasiekina, L.V., \& Zasiekin, S.V. (2008). Psykholinhvistychna diahnostyka [Psycholinguistic Diagnosis]. Lutsk: RVV Vezha [in Ukrainian].

Karelin, A. (2007). Bolshaya entsiklopediya psikhologicheskikh testov [The Great Encyclopedia of Psychological Tests]. Moscow: Eksmo [in Russian].

Kovalevska, T.Y. (2001). Komunikatyvni aspekty neyrolinhvistychnoho prohramuvannya [Communicative Aspects of Neurolinguistic Programming]. Odesa: Astroprynt [in Ukrainian].

Kelly, H. (2000). Osnovy sovremennoy seksolohyy [Basics of Modern Sexology]. St. Petersburg: Pyter [in Russian].

Kon, Y.S. (2004). Seksolohyya [Sexology]. Moscow: Akademyya [in Russian].

Kurganova, N.I. (2019). Assotsiativnyy eksperiment kak metod issledovaniya znacheniya zhivogo slova [An Associative Experiment as a Method of Studying the Meaning of a Living Word]. Voprosy psikholingvistiki - Journal of psycholinguistics, 3 (41), 24-37. https://doi.org/10.30982/2077-5911-2019-41-324-37 [in Russian].

Maslow, A. (2004). Motivatsiya i lichnost [Motivation and Personality]. Kyiv: PSYLIB [in Russian].

Nikitina, C.E. (1993). Ustnaya narodnaya kultura i yazykovoye soznaniye [Oral Folk Culture and Linguistic Consciousness]. Moscow: Nauka [in Russian].

Petrenko, V.F. (2010). Osnovy psikhosemantiki [Basic Psychosemantics]. Moscow [in Russian].

Romanova, N.V. (2012). Psykholinhvistychni metody doslidzhennia emotyvnoi leksyky [Psychological methods of obtaining vocabulary]. Retrieved from https://naub. oa.edu.ua/2012/psyholinhvistychni-metody-doslidzhennya-emotyvnoji-leksyky/ [in Ukrainian].

Selihey, P.O. (2009). Struktura y typolohiya movnoyi svidomosti [Structure and Typology of Linguistic Consciousness]. Movoznavstvo - Linguistics, 5, 12-29 [in Ukrainian].

Serkin, V.P. (2016). Psikhosemantika [Psychosemantic]. Retrieved from https://stud. com.ua/43561/psihologiya/psihosemantika [in Ukrainian].

Temkina, A. (2008). Seksualnaya zhizn zhenshchiny: mezhdu podchineniyem i svobodoy [Woman's Sex Life: Between Submission and Freedom]. St. Peterburg: Izdatelstvo Yevropeyskogo universiteta v Sankt-Peterburge [in Russian].

Freud, Z. (1998). Osnovnyye printsipy psikhoanaliza [The Basic Principles of Psychoanalysis]. Moscow: Refl-buk [in Russian]. 
Shapovalova, V.A. (Ed.). (n.d.). Terminologicheskiy glossariy osnovnykh terminov dinamicheskoy psikhiatrii [Glossary of Basic Terms in Dynamic Psychiatry]. Retrieved from http://vocabulary.ru/slovari/terminologicheskii-glossarii-osnovnyhterminov-dinamicheskoi-psihiatrii.html [in Russian].

Standarty seksualnogo obrazovaniya v Yevrope [Standards for Sexuality Education in Europe]. (2010). Retrieved from http://srhhivlinkages.org/wp/wpcontent/ uploads/2013/04/who_bzga_standards_ru.pdf [in Russian].

Cameron, D. (2010). Sex/Gender, Language and the New Biologism. Applied Linguistics, 31 (2), 173-192. https://doi.org/10.1093/applin/amp022

Cutler, A., \& Scott, D.R. (1990). Speaker sex and perceived apportionment of talk. Applied Psycholinguistics, 11 (3), 253-272. https://doi.org/10.1017/ S0142716400008882

Gawda, B. (2019). The Structure of the Concepts Related to Love Spectrum: Emotional Verbal Fluency Technique Application, Initial Psychometrics, and Its Validation. Journal of Psycholinguistic Research, 48, 1339-1361. https://doi.org/10.1007/ s10936-019-09661-y

Osgood, Ch.E. (1964). Semantic Differential Technique in the Comparative Study of Cultures. American Anthropologist, 66 (3), 171-200. https://doi.org/10.1525/ aa.1964.66.3.02a00880

Sakaluk, J.K., Todd, L.M., Milhausen, R., Lachowsky, N.J., \& Undergraduate Research Group in Sexuality (URGiS). (2014). Dominant Heterosexual Sexual Scripts in Emerging Adulthood: Conceptualization and Measurement. Journal of Sex Research, 51 (5), 516-531. https://doi.org/10.1080/00224499.2012.745473

Snell, W.E.Jr., \& Rigdon, K.L. (2001). The Multidimensional Sexual Perfectionism Questionnaire: Preliminary Evidence for Reliability and Validity. In W.E. Snell Jr. (Ed.), New Directions in the Psychology of Human Sexuality: Research and Theory (Chapter 15). Cape Girardeau, MO: Snell Publications.

Suvivuo, P., Tossavainen, K., \& Kontula, O. (2010). "Can There Be Such a Delightful Feeling as This?» Variations of Sexual Scripts in Finnish Girls' Narratives. Journal of Adolescent Research, 25 (5), 669-676. https://doi. org/10.1177/0743558410366597

\begin{abstract}
АНОТАЦІЯ
У статті представлено результати психолінгвістичного дослідження представленості у мовній свідомості психосемантичної та психологічної наповненості срормованого в умовах природного транскультурного семіозису відносного неологізму «сексуальність». Сформульовано власне визначення феномена сексуальності.
\end{abstract}

Метою дослідження $\epsilon$ вивчення семантичного наповнення поняття "сексуальність», аналіз наявних визнечень, увиразнення поняття сексуальності. Формулювання на основі результатів психосемантичних досліджень власного визначення.

Методи й методики дослідження. Було використано психолінгвістичні методи, як-от: (a) продовжений асоціативний експеримент; (б) модифікований метод семантичного диреренціалу; (в) модифікований метод незакінчених речень. 
Результати. Завдяки продовженому асоціативному експерименту виявлено, що в мовній свідомості студентської молоді (20-22 роки) в розумінні сексуальності найчастіше зустрічається кальковане з американської семантичні асочіати "sеху» - сексуально привабливий (28,27\%). В асоціативному полі осіб віку ранньої дорослості, які виросли в умовах природного мовного семіозису, в якому значення "sеху» ще не було, переважають інші вербальні реакції - довіра, відкритість, безпека, розум, чоловік. Модифікований метод незакінчених речень дав змогу виявити, що психосемантично розуміння сексуальності у чоловіків та жінок має як спільні, так і відмінні риси.

Висновки. Живе слово репрезентує когнітивно-дискурсивну діяльність індивіда та соціуму. Сексуальність як продукт природного семіозису $і$ як психологічний феномен не зводиться до статевості - сексуальної тілесності. Будучи частиною цілісної Я-концепції та осмисленої ідентичності, поняття сексуальності сягає ментально-духовного рівня $і$ активно присутнє у мовній свідомості дорослої людини. Отже, сексуальність функціонує на тілеснофізичному, душевно-емоційному та ментально-духовному рівні і розглядається щонайменше в біологічному, психологічному (психолінгвістичному) та культуральному аспектах.

Ключові слова: мовна свідомість, асочіативні поля, семантичний простір, психосемантика сексуальності, асоціативний експеримент, сексуальність.

\section{Шевцов Андрей \& Гупаловская Виктория. Психосемантическое содержание понятия сексуальности в языковом сознании взрослых}

\section{АННОТАЦИЯ}

В статье представлены результаты психолингвистического исследования представленности в языковом сознании, психосемантической и психологической наполненности сформированного в условиях естественного транскультурного семиозиса относительного неологизма "сексуальность». Сформулировано собственное определение феномена сексуальности.

Целью исследования является изучение семантического наповнення понятия "сексуальность", анализ имеющихся определений, формулирование на основании результатов психосемантических исследований собственного определения понятия "сексуальность».

Методы и методики исследования. Использованы психолингвистические методы, в частности: (а) продолженный ассоциативный эксперимент; (б) модифицированный метод семантического дифреренциала;

(в) модифицирований метод незаконченных предложений.

Результаты. Благодаря продолженному ассоциативному експерименту выявлено, что в языковом сознании студенческой молоди (20-22 года) в понимании сексуальности чаще всего встречаются копированные из американского английского семантические ассоциаты "sеху» - сексуально привлекательный (28,27\%). В ассоциативном поле опрошенных возраста ранней взрослости, которые вырослы в условиях естественного языкового 
семиозиса, в котором значения "sеху» еще не было, преобладают другие вербальные реакции - доверие, открытость, безопасность, ум, мужчина. Модифицированный метод незаконченных предложений позволил выявить, что психосемантическое наполнение сексуальности у мужчин и женщин имеет как общие, так и отличительные черты.

Выводы. Живое слово репрезентирует когнитивно-дискурсивную деятельность индивида и социума. Сексуальность как продукт природного семиозиса и как психологический феномен не может быть сведена к сексуальной телесности. Будучи частью целостной Я-концепции и осмысленной идентичности, понятие сексуальности достигаєт ментально-духовного уровня и активно присутствует в языковом сознании взрослого человека. Сексуальность функционирует на телесно-фризическом, душевно-эмоциональном и ментальнодуховном уровне и рассматривается кек минимум в биологчческом, психологическом (психолингвистическом) и культуральном аспектах.

Ключевые слова: языковое сознание, ассоциативные поля, семантическое пространство, ассоциативный эксперимент, психосемантика сексуальности, сексуальность. 